IZA DP No. 5557

Social Housing and Location Choices of Immigrants in France

Denis Fougère

Francis Kramarz

Roland Rathelot

Mirna Safi

March 2011 


\title{
Social Housing and Location Choices of Immigrants in France
}

\author{
Denis Fougère \\ CNRS, CREST, CEPR and IZA \\ Francis Kramarz \\ CREST(INSEE), CEPR and IZA \\ Roland Rathelot \\ CREST \\ Mirna Safi \\ Sciences Po and CREST
}

Discussion Paper No. 5557

March 2011

IZA

P.O. Box 7240

53072 Bonn

Germany

Phone: +49-228-3894-0

Fax: +49-228-3894-180

E-mail: iza@iza.org

\begin{abstract}
Any opinions expressed here are those of the author(s) and not those of IZA. Research published in this series may include views on policy, but the institute itself takes no institutional policy positions.

The Institute for the Study of Labor (IZA) in Bonn is a local and virtual international research center and a place of communication between science, politics and business. IZA is an independent nonprofit organization supported by Deutsche Post Foundation. The center is associated with the University of Bonn and offers a stimulating research environment through its international network, workshops and conferences, data service, project support, research visits and doctoral program. IZA engages in (i) original and internationally competitive research in all fields of labor economics, (ii) development of policy concepts, and (iii) dissemination of research results and concepts to the interested public.
\end{abstract}

IZA Discussion Papers often represent preliminary work and are circulated to encourage discussion. Citation of such a paper should account for its provisional character. A revised version may be available directly from the author. 
IZA Discussion Paper No. 5557

March 2011

\section{ABSTRACT}

\section{Social Housing and Location Choices of Immigrants in France}

Our study examines the empirical links between social housing policy and location choices of immigrants in France. More specifically, we characterize the main individual and contextual determinants of the probability for immigrants to live in a HLM (habitations à loyer modéré, dwelling with a moderate rent), which is the main public housing policy in France. For that purpose, we use individual information coming from large (one-fourth) extracts of the French population censuses conducted by INSEE (Paris) in 1982, 1990, and 1999. Our estimates show that, in general, migrants live more frequently in social housing than French natives, other observables being equal. In particular, this probability is higher for migrants from Turkey, Morocco, Southeast Asia, Algeria, Tunisia and Sub-Saharan Africa (in descending order). We find also that migrants of all origins live less often in a HLM when the city has plenty of social housing and when the fraction of natives is high.

JEL Classification: J61, I38, R38

Keywords: social housing, migration, social magnets

Corresponding author:

Denis Fougère

CREST-INSEE

15 Boulevard Gabriel Péri

92245 Malakoff Cedex

France

E-mail: fougere@ensae.fr 


\section{Introduction}

In the context of increasing ethnic and racial tensions in several European countries and growing influence of far right political parties in some of these countries, welfare use by immigrants (and more generally, the cost of immigration) is gaining importance in both the political and scientific debates. Research on this topic has emerged in the 1990s' in the USA leading to some controversial findings (Borjas (1990); Borjas (1999); Kaushal (2005)). In Europe, and particularly in France, such studies remain very rare. Recently, some empirical research tried to measure immigrants' responses to differences in welfare systems across European countries. The idea is to measure the extent to which the choice of a destination country within the European continent is correlated with the more or less generosity of its welfare system. Research on this topic finds little empirical support to the welfare magnets hypothesis elaborated by Borjas (Brucker, Epstein, McCormick, Saint-Paul, Venturini, and Zimmermann (2002); Nannestad (2007)). Moreover, several studies address the issue of the validity of the welfare magnets approach in the European context. Immigration legislations and policies are so different across European countries, on the one hand, and the process of legal immigration is so difficult in the context of restrictive policies widespread all over the continent, on the other hand, that speaking of immigrants' choices of their destination country is quite unrealistic. Evidence has been more convincing on immigrants' responses to geographical differences in the sizes of the foreign-born populations, or co-ethnics populations, rather than to welfare differentials (Card (2007); Edin, Fredriksson, and Åslund (2003); Zavodny (2005)). Network effects seem to be more powerful than welfare magnets.

However, the literature on immigration and welfare is also interested in measuring the extent to which immigrants' financial contribution to the welfare system is more of less significant than their welfare dependency. Here the underlying hypothesis is that immigrants' welfare dependency is higher than the one of comparable natives, because of a moral hazard issue specific to immigration (Nannestad (2007)). This approach is typical of the economic approach of immigration in terms of a cost-benefit analysis (see, for instance, Borjas (1994)). Studies on this 'welfare gap' have been 
set forth both in the USA and in Europe (see, for instance, Hansen and Lofstrom (2003)). Borjas and Hilton (1996) find that only a minor part of the initial gap between natives and immigrants remain unexplained after controlling for a wide range of covariates. In Europe, Brucker, Epstein, McCormick, Saint-Paul, Venturini, and Zimmermann (2002) study this gap across several European countries and find some support for the hypothesis of immigrants' specific moral hazard. De Giorgi and Pellizzari (2009) explore the issue of welfare migration across the countries of the pre-enlargement European Union and find a significant but small effect of the generosity of welfare on migration decisions. More recently, a French study has tried to measure immigrants' welfare dependency in France (Gélot and Minni (2009)). The authors find that African immigrants are more dependent on welfare, as far as employment and income measures are concerned. However, African immigrants seem to have a lower access to some public services, such as health care and housing.

Despite some empirical support for a higher immigrants' dependency on welfare, the interpretation of these findings does not go without saying. Immigrants' dependency may indeed be related to their exposure to intense ethnic and racial discrimination in the labour and housing markets. It may also reflect their higher vulnerability to the economic situation (i.e. they are the first to be laid off during recessions). This is the reason why policy implications of the literature on immigration and welfare are still controversial. Should the State exclude migrants (especially recently arrived ones) from some welfare programs, or should it rather increase the social protection of immigrants, especially during economic crisis?

There is now a substantial economic literature on the location choices of immigrants in their destination countries. For instance, in a pioneering study, Bartel (1989) has shown that post-1964 U.S. immigrants are more geographically concentrated than natives of the same age and ethnicity, and reside in cities with a large ethnic population. In a much-quoted article, Borjas (1999) found that U.S. immigrant welfare recipients are more heavily clustered in high-benefit states that the immigrants who do not receive welfare, or than natives. This finding was then disputed by Kaushal (2005) who finds that safety-net programs have little effect on the location choices of newly arrived 
low-skilled unmarried immigrant women. In Europe, some studies have also examined the welfare participation rates of immigrants. For instance, in an empirical analysis using Swedish data, Hansen and Lofstrom (2003) find that immigrants use welfare to a greater extent than natives, and that differences cannot be explained by observable characteristics. However, to the best of our knowledge, no econometric study has focused on the access of immigrants to social housing programs which are frequently implemented in Europe.

Our study is devoted to this specific issue. It examines the empirical links between social housing policy and location choices of immigrants in France. In France, the main public housing policy is the HLM (habitations à loyer modéré, dwelling with a moderate rent) program. Any family is eligible for residing in a HLM dwelling provided that the head of the family is allowed to live in France and that income per unit of consumption lies below a threshold, which depends on the region of residence and is updated each year. Eligible families may apply for a HLM in any city (commune) where such public programs exist, regardless of their current place of residence or nationality. Today, more than 12 millions of persons live in a HLM.

Despite the fact that in France, migration waves were quite intense during the launching of the first program of HLM construction, the massive presence of immigrants in such dwellings is rather a recent phenomenon (Barou (2002); Barou (2006)). Up to the sixties, immigrants lived overwhelmingly in shanty towns, either in very insalubrious hovels or in private cheap hotels. In year 1971, the government decided to demolish these uninhabitable buildings and immigrants were gradually rehoused, mostly in HLM. However, Pinçon (1981) shown that immigrants had at that time a lower probability to live in a HLM dwelling, once socioeconomic covariates were taken into account. In particular, his study shed light on the intense selection mechanisms of immigrants who were accepted in HLM dwellings. According to him, the HLM administration was indeed concerned about the quality of "cohabitation" between natives and immigrants, which was perceived as problematic especially for non European migrants. From the nineties, immigrants, and also more generally low-income native families, began to be more and more numerous in HLM dwellings (Barou (2005)). Moreover, at the same moment, residential mobility out of the HLM 
drastically decreased.

In this paper, we characterize the main individual and contextual determinants of the probability to live in a HLM for immigrants residing in France. We use individual information coming from large extracts of the French population censuses conducted by INSEE (Institut National de la Statitstique et des Etudes Economiques, Paris) in 1982, 1990, and 1999. The census source is especially relevant for our study since it allows us to deal with significant samples of immigrants, according to their origin country, these groups being generally too small in French surveys. It contains relevant information about the observable individual characteristics of immigrants (country of birth, age, marital situation, occupation, human capital, etc.). We add to this information some contextual variables that are extracted from the exhaustive censuses. For instance, we precisely know the size of the migrant's community and the number of foreigners in his/her city (commune) of residence, but also the number of persons living in HLM buildings in this city at each census date. Our first objective is thus to estimate the effects of these individual and contextual covariates on the probability to live at a given date (namely, at the date of the census) in a HLM for natives and for the different groups of immigrants (according to their country of origin, the size of their family, their education, their age, etc.), and the evolution of this probability through time. The identification of the model is permitted by the fact that the proportion of persons living in HLMs varies across cities (communes) and over time.

\section{Data}

\subsection{Statistical sources and variables}

For more than a century France has been an immigration country and was one of the first in Europe. However, France does not officially recognize an ethnic status within its population, so ethnicity must be inferred by foreign-birth status. Consequently, the migrants consist of those in France who did not have French nationality at birth but could have obtained it after. Within this 
group we can distinguish between different subgroups according to the countries of origin. The main groups of migrants include those born in Spain, Italy, Portugal, Algeria, Morocco, Tunisia, Turkey, Cambodia, Laos and Vietnam. Other migrants are classified by groups of countries (other European countries, other African countries, other Asian countries, America and Oceania).

Migrants in France can be identified through different data sources. The main source is the general Population Census, which was last carried out for the whole population in 1999. Other notable surveys include the Labor Force Surveys (Enquêtes sur l'emploi) conducted by the Paris based Institut National de la Statistique et des Etudes Economiques (INSEE) annually up to 2002 and quarterly since 2003.

According to the French population census which occurred in 1999, a total of 4,306,094 migrants resided in France that year. These migrants represented 7.36 per cent of a total population of 58520 688. The main groups of migrants were from other European countries, Africa and Asia. The 1934144 migrants from European countries represented 45.0 per cent of the total number of migrants. They mainly came from Portugal (571 874), Italy (378 649) and Spain (316 232). African migrants (1 691 562) mainly came from Algeria (574 208), Morocco (522 504), Tunisia (201 561) and from sub-Saharan Africa (393 289). They represented 39.3 per cent of the total number of migrants. Asian migrants (549 994) mainly came from Turkey (174 160), and Cambodia, Laos and Vietnam (159 750). They represented 12.7 per cent of the total number of migrants. ${ }^{1}$

The proportion of migrants from Africa has increased over time: they accounted for 33.2 per cent of migrants in 1982 rising to 39.3 per cent in 1999. This increase was especially marked for migrants from sub-Saharan African countries. In contrast the proportion of migrants from European countries decreased over the same period. European migrants accounted for 57.3 per cent of migrants in 1982 falling to 45.0 per cent in 1999. This decrease was especially attributable to migrants from Spain and Italy.

Migrants are older than the non-migrants. In 199912.7 per cent of migrants were younger

\footnotetext{
${ }^{1}$ This overall analysis is presented in more detail in the survey on immigration in France written by Fougère (2010).
} 
than 24 years old (31.0 per cent in the whole population), 36.6 per cent were aged between 25 and 44 (29.1 per cent in the whole population), 32.9 per cent were aged between 45 and 64 (23.4 per cent in the whole population), and 17.8 per cent were older than 65 (16.7 per cent in the whole population). The oldest are Spanish and Italian migrants, since they belong to the oldest immigration waves; the youngest are migrants from Morocco, Turkey and Sub-Saharan countries.

To limit the difficulties associated with the analysis of very large samples (since, by definition, population censuses are exhaustive), we have concentrated our statistical analysis to one-fourth random subsamples of three censuses, namely those conducted in years 1982, 1990, and 1999. These subsamples provide precise information about individual socioeconomic characteristics, such as age, sex, education, matrimonial status, socioprofessional category, employment status, country of birth and current nationality (i.e., at the date of the survey). ${ }^{2}$ They also contain information about the type of dwelling in which the survey respondents live, and in particular whether they live in a social housing dwelling at the census date. Moreover, using data from the exhaustive censuses, we have augmented this individual set of characteristics by adding local contextual covariates, such as the total number of inhabitants in the city (commune) where the survey respondent lives, the proportion of persons living in social housing dwellings and the proportions of migrants from the various possible origins in this city.

\subsection{Descriptive statistics}

Table 1 reports the proportions of persons residing in France at each census date (1982, 1990, 1999), according to their country (or region) of origin. These proportions are computed for people living in France and older than 18. The population living in France is composed of approximately 90 per cent of natives (defined as persons born French on the French territory). This proportion remains stable over the period 1982-1999. Foreign born individuals and those who are born

\footnotetext{
${ }^{2}$ According to Fougère and Safi (2009), over the last ten years, 125,000 persons gained French nationality each year on average. In France, foreign-born residents can become French either by decree, namely by decision of the public authorities at the request of a foreigner and whether some conditions are fulfilled, or by declaration, after a marriage with a spouse of French,nationality.
} 
foreigners on the French territory form the remaining 10 per cent. ${ }^{3}$

For each country (or region) of origin, Table 1 reports the total proportion of immigrants living in France at the date of the census, but also the proportion of those who have gained the French citizenship. ${ }^{4}$ Statistics calculated within the one-fourth extracts of censuses are in line with those obtained by using the exhaustive population (Fougère 2010). Migrants from Southern Europe (Portugal, Spain, Italy) form the most sizeable group, corresponding to 4 per cent of the total population in 1982, and to 3.6 per cent in 1999. Migrants from Northern Africa (Algeria, Morocco, Tunisia) come next, representing 2.5 per cent of the French population in 1982, and 2.9 per cent in 1999. The proportion of migrants having gained French citizenship is higher within the group of migrants from Southern Europe (51 per cent in 1999) than within the group of migrants coming from Northern Africa (34 per cent in 1999).

As far as it is possible, the subsequent statistical analysis will try to distinguish the country of origin for the immigrants coming from these six countries (Portugal, Spain, Italy, Algeria, Morocco, Tunisia) since they correspond to the largest migrant groups living in France. The other groups of immigrants being less numerous, we are obliged to aggregate them for statistical purposes. Thus immigrants from Southern-Eastern Asia (Cambodia, Laos, Vietnam) are grouped together. This is also the case for those coming from Sub-Saharan Africa, from Eastern Europe, from other countries of Western Europe (excluding Spain, Italy and Portugal), and from Northern and Southern America.

\section{[Insert Table 1 around here]}

Table 2 provides information on sociodemographic characteristics of immigrants and natives. Compared to natives, immigrants are less frequently managers, engineers, or executives, more often blue-collar workers or unemployed. They are also more often employed in the private sector. They are significantly less educated, but this educational gap has decreased over our time period.

\footnotetext{
${ }^{3}$ In France, immigrants' children become French when they turn 18, provided that they were born in France.

${ }^{4}$ In our analysis, the term "immigrant" refers to the foreign born population. The acquisition of the French citizenship and its consequences on the employment status of immigrants residing in France has been studied by Fougère and Safi (2009).
} 
For instance, in 1999, the proportion of individuals who graduated from a university (4 years of schooling after the baccalauréat, which is high-school final exam in France) is higher among the migrants.

[Insert Table 2 around here]

\subsection{Who lives in social housing units?}

In France, social housing can be built and/or managed by either public or private agencies. It includes a wide range of habitations: collective buildings, individual apartments in a block of individually owned flats, private housing estate, etc. Moreover, social housing can be rented (which is the case for the majority of households living in social housing units) or owned. However, census information concerning social housing does not reproduce this variety of situations. In the 1982 French census, information about social housing corresponds to the whole building the household lives in, while in the 1990 and 1999 censuses, the information concerns either the individual

apartment occupied by the interviewee or the whole building he/she lives in. In order to be able to compare the three censuses, we thus define the dependent variable as the occupancy of a housing unit in an HLM building. Depending on the census date, we sometimes know if the social housing unit is rented or owned, but here again, we do not distinguish between these two occupancy statuses for comparability concerns.

Usually, the only pre-requisite to apply to social housing is to earn below a certain threshold (defined by the municipality). However, this does not mean that everyone who is eligible will have access to social housing. Indeed, in order to increase social diversity in social housing and to avoid the ghettoization of the most disadvantaged populations, the thresholds are far for being low; theoretically, 60 to $70 \%$ of the French population is indeed eligible to occupy a social housing unit according to the income thresholds. This is clearly above the $20 \%$ legal target which is far from being effectively reached in every municipality. In a context of increasing real estate's prices and growing difficulties in accommodation for middle and lower classes, this inevitably leads to a 
situation of sharp rationing in the social housing market. In Paris, for example, there are 100,000 applications each year (among which 40,000 are new), but only 8,000 housing units are allocated a year (Dietrich-Ragon 2010). Applications are ranked according to emergency criteria, among which extreme health and family reasons are the most important.

Once obtained, a social housing unit is very seldom vacated, which participates to the rationing of the market. Eviction is a very complex, long and costly procedure that is almost never engaged by social housing agencies. This leads to situations of durable - not to say endless - occupation, and sometimes quasi-inheritance, of social housing units within some privileged (or newly privileged) populations. In 2009, a new law has abolished the right of HLM occupants to stay in their habitation as soon as their income is more than twice the threshold.

Most of French municipalities are of small size. According to census data, the average size of a French municipality is 1,491 inhabitants, the median being only 352 inhabitants. This implies for instance that, in the 1982 census, only one municipality out of four $(8,689$ out of 36,420$)$ has more than one inhabitant living in a social housing unit. Among these 8,689 municipalities, the proportion of inhabitants living in social housing units is quite heterogenous, quartiles of the distribution of proportions being equal to $2.9 \%, 6.6 \%$ and $13.4 \%$. The municipality size and the proportion of social housing units are positively correlated. For instance, in 1982, the median size of municipalities with no social housing units was equal to 256 inabitants, while it was equal to 4,228 for municipalities where the proportion of persons living in social housing units was greater than $13.4 \%$. This was equally true in 1999 .

Another issue is the stability of social housing over the period: were social-housing-friendly municipalities the same in 1982 and 1999? To answer this question, we rank municipalities according to their proportion of social housing units. We then consider five groups: the first group includes municipalities with no social housing units, while the four remaining groups correspond to the quartiles of the ditribution of the proportion of persons living in social housing units (given that this proportion is strictly positive). We then compute the transition matrix across these five categories between 1982 and 1999. While municipalities in the extreme groups (namely, with 
either many or no social housing units), are mostly the same in 1982 and 1999, it is not so true for intermediate categories. For instance, only $26 \%$ of municipalities who were in the second quartile in 1982 were still in this quartile in 1999. This result is actually a matter of size. If we restrict the analysis to the 7,624 municipalities with more than 1,000 inhabitants in 1982, the proportion of persons living in social housing units drastically increased over the period: $83 \%$ of municipalities with no social housing units in 1982 built some in the period; 21\% even reached the second quartile in 1999. For the 22,332 municipalities with less than 500 inhabitants in 1982, the change is in the opposite direction: $88 \%$ of those with no social housing units in 1982 had still no social housing units in 1999.

Finally, how are population changes correlated with the supply of social housing units? For that purpose, we calculate the average variation in the total and immigrant populations within each municipality between 1982 and 1999, according to the five previously defined categories. Overall, the total population increased in all categories, but less in the first one with no social hosuing units (63 on average vs. 336 in the fourth quartile). The increase in the number of immigrants is even stronger when there were initailly more social housing units in the municipality (2 on average in municipalities with no social housing units vs. 156 in the fourth quartile). Restricting the analysis to municipalities with less than 500 inhabitants, we find that these results vanish: the increase in the total population and in the number of immigrants is more or less the same in the five categories. Conversely, for the municipalities with initially more than 1,000 inhabitants, the correlation between the variation in the number of immigrants and the initila proportion of persons living in social housing units is maximum. Initially more social housing is correlated with more immigrants and especially more immigrants from North Africa.

Table 3 presents the proportions of people living in a social housing dwelling, according to their country (or region) of origin and their status with respect to French citizenship. Immigrants from Algeria, Morocco, Turkey, Tunisia, Sub-Saharan Africa and Southern-Eastern Asia are, by far, the groups that most likely live in a social housing dwelling. Whereas almost 16 per cent of French natives live in a social housing dwelling in 1999, this proportion exceeds 50 per cent for Al- 
gerian, Moroccan and Turkish immigrants who do not have the French citizenship. It is comprised between 40 and 50 per cent for Tunisians and Sub-Saharan Africans. Western Europeans (excluding migrants from Spain, Italy and Portugal) and Northern Americans live very unfrequently in social housing. Having gained French citizenship does not seem to increase the probability to live in a social housing dwelling, except for migrants coming from Sub-Saharan countries. For instance, the proportions of migrants living in a social housing dwelling in 1982 were in general lower among those having gained Frecn citizenship than among those who did not have French citizenship. However, these proportions have get closer in 1999.

[Insert Table 3 around here]

Figure 1 presents the local proportions of persons living in social housing dwellings. They are computed by using an optimal bidimensional kernel applied to count data at the city (commune) level. Social housing dwellings are mostly located in the Northern part of France and in the biggest cities. The proportions are almost the same in 1982 and 1999. Looking into details, the few increases mostly occur in cities where social housing was scarce in 1982.

[Insert Figure 1 around here]

Figure 2 depicts the local proportions of individuals living in HLM in 1982 (left panel) and 1999 (right panel) in Paris and the administrative region around, called Ile-de-France. In Ile-de-France as in the whole country, these proportions and the locations where they are the highest ones have not much changed over the period. In this period, social housing dwellings are mainly located in zones where plants are concentrated (in particular along the river Seine).

[Insert Figure 2 around here] 


\section{Social housing and immigrants}

\subsection{The geographical location of immigrants over time}

The geographical distribution of immigrants on the French territory is mainly related to historical factors (Noiriel 2002). In almost all immigration countries, waves of immigrants do not initially spread homogeneously over the whole territory resulting in a self-generating processus of unequal geographical distribution. Interestingly, the geographical location of immigrants in France has been quite stable over time, as displayed by Figure 3 .

In its upper panel, this figure reports the proportions of immigrants calculated at the local (city) level in years 1982 and 1999. The medium and lowest panels present proportions of immigrants from North Africa (Algeria, Morocco and Tunisia) and from Southern Europe (Spain, Italy and Portugal), respectively. These proportions are computed using the same method as in Figure 1. The immigrant population in France is rather concentrated in the Eastern part of the country. Immigrants are more numerous around Paris (in the region called Ile-de-France) and in the South-East of France. This pattern varies across immigrant groups. While North Africans are geographically distributed like the whole immigrant population, Italians, Portuguese and Spanish are concentrated in three regions: the Southern-Western part of France, the Alps, and the Paris region.

[Insert Figure 3 around here]

Figure 4 represents the local proportions of immigrants in Ile-de-France (i.e. the region around Paris) in 1982 (left column) and in 1999 (right column). The most notable fact is the significant increase of the proportion of immigrants coming from Sub-Saharan countries over the period. The increase occurred almost everywhere in the region, with the exception of its eastern part. On the contrary, the proportions of immigrants from Southern Europe living in Ile-de-France have decreased over the period. The proportions of immigrants from North African countries, and their place of residence, have been stable. 
[Insert Figure 4 around here]

\subsection{Social housing and immigrants : odds ratios}

Figure 5 presents odds-ratios for the conditional probability to live in a social housing dwelling, given that the individual is an immigrant, an immigrant from Maghreb, or an immigrant from Southern Europe, respectively in years 1982 and 1999. Thus $\mathbb{P}_{s}[H L M \mid I m m]$ denotes the probability for an immigrant residing in the city (commune) $s$ to live in a social housing dwelling, and $\mathbb{P}_{s}[H L M \mid N a t]$ denotes the corresponding probability for a French native residing in the same city $s$. Then the odds-ratio is defined as:

$$
O R(I m m)=\frac{\mathbb{P}_{s}[H L M \mid I m m]}{\mathbb{P}_{s}[H L M \mid N a t]}
$$

The values of this ratio $O R$ indicate to what extent immigrants (or a given subgroup of immigrants) are more or less likely to live in social housing than natives. For instance, if the oddratio is greater than one, it means that immigrants are more likely than natives to live in a HLM in that city. Figure 5 provides the local values of the odds-ratios $O R(\operatorname{Imm}), O R($ Maghrebian $I m m)$ and $O R(S E I m m)$.

[Insert Figure 5 around here]

Comparing Figures 1, 3 and 5, provides a first set of facts about inequality in immigrants access to social housing over French territory. While immigrants are very concentrated around Paris, it is striking to notice that the odds-ratio of the probability to live in a HLM for an immigrant is less than 1 in this region. This probability is surprisingly higher in more rural areas, which do not include the biggest cities and are less densely populated, such as Britanny and the center of France (where immigrants are very rare; see Figure 3). The results do not change much from 1982 to 1999, except for Southern Europeans. In 1982, their probability of living in a social housing dwelling is very high almost everywhere in France. In 1999 however, this probability has decreased in most of 
the areas, but it remains high in Britanny and the South East of France. This suggests that social housing might have worked as a transitional accommodation facility for these populations (as it is also often the case for natives), as explicited in Edou (1998) or Barou (2002). As far as they get more and more assimilated into French society, Italians, Spanish and Portuguese leave social housing and most probably for private housing or home ownership. This does not seem to be the case for North Africans; their patterns of residence in social housing buildings are very similar in 1982 and 1999, which suggests that they remain in this type of housing much longer than migrants from Southern European migrants. More suprisingly, the areas where their probability to live in a social housing building is higher are located in regions where their presence is rather low.

Focusing on the region around Paris shows that, between 1982 and 1999, the probability to live in a social housing dwelling conditional on being an immigrant from Sub-Saharan Africa, an immigrant from North-Africa, or an immigrant from Southern Europe, has decreased for all immigrants in this region, especially for those coming from Sub-Saharan and Southern-European countries (see Figure 6).

[Insert Figure 6 around here]

Of course, the previous analysis is just descriptive. The following section is devoted to a regression analysis that helps understanding the extent to which observable personal and city characteristics may explain these descriptive patterns.

\subsection{Social determinants for living in social housing}

Table 4 reports parameter estimates of a linear probability model in which the explained variable is the proportion of persons living in a social housing dwelling within a given cell. ${ }^{5}$ In fact, most cells comprise only a very limited number of observations. Hence, the data are virtually

\footnotetext{
${ }^{5}$ The cells are obtained by crossing all the possible values of the covariates considered in the models. The standard errors of the estimates take into account the fact that statistical units are cells, and not individuals, by using the heteroskedastic covariance matrix adapted to clusters. Estimates reported in Tables 5 and 6 are also obtained by applying the same method.
} 
individual. In particular, the city is identified and its interaction with person level characteristics allow us to have a very large number of observations per city and per year. Hence, all ensuing Tables include city fixed effects. Results reported in Table 4 show that in general, migrants live more frequently in social housing buildings than French natives, other observables being equal. In particular, this probability is higher for migrants from Turkey, Morocco, Southeast Asia, Algeria, Tunisia and Sub-Saharan Africa (in descending order). It is generally lower for migrants who have gained French citizenship (excepted for migrants from Sub-Saharan Africa). Women are more likely to live in a social housing dwelling than men. It is also the case for singles and lone mothers. Socio-professional category and educational attainment also have a highly significant effect on this probability. It is higher for blue-collar and white-collar workers, unemployed workers, but also for public firm workers and civil servants. This probability is a decreasing function of age, but it has increased through time, because of the increase in the public housing stock over the period.

\section{[Insert Table 4 around here]}

Tables 5 incorporates second-order interaction terms between the geographical origin of migrants (Northern Africa, Southern Europe, other countries) and some contextual local covariates, such as the logarithm of the city population, the proportion of persons living in public housing dwellings in this city, and the proportions of migrants from Northern Africa, Southern Europe or other countries (excluding Spain, Italy, Portugal, Algeria, Morocco and Tunisia) in the same city. Southern Europeans are the only migrants more likely than natives to live in a public housing dwelling when the size of the city is large. In addition, all migrants are more likely (than natives) to live in a HLM when the proportion of people living in social housing is large. However, North Africans are less likely to live in a HLM than natives when the fraction of migrants, including themselves, is large in the city. Because the fraction of natives in the city is equal to one minus the sum of all groups of migrants, it essentially means that North Africans are more likely to live in a HLM when the proportion of natives is large in the city. Interestingly, this feature is observed for all groups of migrants. Hence, migrants tend to live in HLM when many natives live in the 
city.

[Insert Table 5 around here]

Table 6 improves on Table 5 by introducing third-order interactions between the individual origin of the migrants, the fraction of people living in a HLM in the city, and the fraction of migrants of each origin in the city. Again, the omitted category comprises the natives. First, let us examine the main second-order effects. They are broadly in line with those found in Table 5. Here, though, all migrants are less likely to live in a HLM than natives in large cities (Southern Europeans rather than positive in Table 5 are identical to natives in this respect). Again, when the fraction of inhabitants living in a HLM is large in the city, migrants are less likely than natives to inhabit a HLM. Again, in broad agreement with results in Table 5, migrants are in general more likely to live in a HLM when the fraction of natives is large in the city. Now, the third-order interactions show that, in cities with many HLMs and many migrants (irrespective of the origin), migrants are less likely to inhabit a social housing. Put differently, migrants of all origins live less often in a HLM when the city has plenty of social housing and when the fraction of natives is high. Can we talk of discrimination? There is no causal evidence, just some indicative elements.

[Insert Table 6 around here]

To understand how the allocation of migrants, HLM housing, and migrants within HLMs, evolved through time and space, Table 7 presents regressions of indicators for individuals living in a HLM, being native... on a full set of city indicators. Each line corresponds to a variable, each column corresponds to a Census year. The Table presents the R-square of the regression. Hence, it measures the amount of dispersion explained by the city and time in each of the variables under study. Results show the following. First, HLM are extremely "dispersed" across France: some cities have zero HLMs when others have a lot. Natives are apparently quite inequally "dispersed", more than migrants at least. Surprisingly, migrants are more inequally spread out over the French territory than natives. Furthermore, "segregation" increased over the period for natives as well as for other migrants, except Southern Europeans who have had the tendency to be spread more 
equally over the French territory. Finally, among those living in HLMs, North Africans and other

migrants have become more and more "segregated" when natives and Southern Europeans have become less so.

[Insert Table 7 around here]

Finally, Table 8 shows the results of a regression of the difference in the proportions of different groups of migrants in 1999 on the same difference in proportions in 1982. Essentially, if the coefficient is small or even negative, it means that there is no persistance, or even reversion in the location choices of migrants. If the coefficients are positive, then initial choices (sometimes forces, indeed) persist. And this is what we observe. Most coefficients are close to one.

[Insert Table 8 around here]

\section{Conclusion}

In this study, we have examined the empirical links between social housing policy and location choices of immigrants in France. More specifically, we have tried to characterize the main individual and contextual determinants of the probability for immigrants to live in a HLM, which is the main public housing policy in France. For that purpose, we use individual information coming from large (one-fourth) extracts of the French population censuses conducted by INSEE (Paris) in 1982, 1990, and 1999 .

Our estimates show that, in general, migrants live more frequently in social housing than French natives, other observables being equal. In particular, this probability is higher for migrants from Turkey, Morocco, Southeast Asia, Algeria, Tunisia and Sub-Saharan Africa (in descending order). It is generally lower for migrants who have gained French citizenship (excepted for migrants from Sub-Saharan Africa).

We find also that migrants are less likely to live in a HLM than natives in large cities. When the fraction of inhabitants living in a HLM is large in the city, migrants are less likely than 
natives to live in a HLM. Moreover, migrants are in general more likely to live in a HLM when the fraction of natives is large in the city. On the whole, in cities with many HLMs and many migrants (irrespective of the origin), migrants are less likely to inhabit a social housing. Put differently, migrants of all origins live less often in a HLM when the city has plenty of social housing and when the fraction of natives is high.

The ongoing economic crisis should create greater difficulties in the access of immigrants to social housing. Several official reports have underlined that, nowadays in France, 3.5 millions of persons are living in poor housing conditions and that 1.5 million of persons are waiting to have access to an HLM dwelling. ${ }^{6}$ This excess demand may correspond to 900,000 dwellings. This explains why housing prices have increased by 150 percent on average between 1995 and 2008, while the average income of households has only increased by 60 percent during the same period. Meanwhile, rents rose twice as fast as inflation. Nowadays, expenses related to housing correspond to 33 percent of the household average disposable income. No doubt that immigrants will bear the brunt of this shortage in the next few years. Policy recommendations which could help to limit their difficulties include a substantial and fast increase in the supply of public housing, but also the introduction of a more equitable procedure of allocation of applicants to HLM dwellings (by using, for instance, anonymous applications).

In a further study, we will concentrate both on the movements between public and private housing both for natives and for immigrants. This study, that will use individual longitudinal data, should improve our understanding on the impact of the French public housing policy on location choices of immigrants.

\footnotetext{
${ }^{6}$ See, for instance, the newspaper "Le Monde" dated Wednesday, May 5, 2010, page 16.
} 


\section{References}

BARou, J. (2002): L'habitat des immigrés et de leurs familles. La documentation française.

— (2005): "HLM, le risque d'une homogénéisation par le bas. Les effets des ségrégations," Informations Sociales, 123(3), 74-87.

(2006): "Bref panorama de la situation des immigrés," Hommes et Migration, 1264, 6-19.

BARTEL, A. P. (1989): "Where Do the New U.S. Immigrants Live?," Journal of Labor Economics, $7(4), 371-91$.

BorJas, G. J. (1990): Friends or Strangers: the Impact of Immigrants on the U.S. Economy. Basic Books, New-York.

— (1994): "The Economics of Immigration," Journal of Economic Literature, 32, 1667-1717. (1999): "Immigration and Welfare Magnets," Journal of Labor Economics, 17(4), 607-37.

BorJAs, G. J., AND L. HiLton (1996): "Immigration and Welfare State: Immigrant Participation in Means-Tested Entitlement Programs," The Quarterly Journal of Economics, 111, 575-604.

Brucker, H., G. S. Epstein, B. McCormick, G. Saint-Paul, A. Venturini, and K. ZimMERMANN (2002): "Managing Immigration in the European Welfare State," in Immigration Policy and the Welfare State, ed. by G. H. Boeri, T., and B. McCormick. Oxford University Press, Oxford.

CARD, D. (2007): "How Immigration Affects U.S. Cities," Discussion Paper Series CDP No. 11/07, Center for Research and Analysis of Migration.

De Giorgi, G., And M. Pellizzari (2009): "Welfare Migration in Europe," Labour Economics, 16(4), 353-363. 
Dietrich-Ragon, P. (2010): "Les mal-logés parisiens face à la logique de l'urgence," Lien Social et Politiques, 63, 103-115.

Edin, P.-A., P. Fredriksson, and O. Åslund (2003): "Ethnic Enclaves and the Economic Success of Immigrants - Evidence from a Natural Experiment," Quarterly Journal of Economics, $118,329-357$.

Edou, E. (1998): Les HLM. Economica, Paris.

Fougère, D., And M. SAFi (2009): "Naturalization and Employment of Immigrants in France (1968-1999)," International Journal of Manpower, 30(1-2), 83-96.

Fougère, D. (2010): "Has the French Model of Integration Broken Down?," in Ethnic Diversity in the European Labor Markets: Challenges and Solutions, ed. by M. Kahanec, and K. F. Zimmermann. Edward Elgar Publishers.

GÉLot, D., And C. Minni (2009): "Présence des personnes d'origine étrangère dans les minima sociaux et retour à l'emploi," Politiques sociales et familiales, 95, 45-57.

Hansen, J., And M. Lofstrom (2003): "Immigrant Assimilation and Welfare Participation Do Immigrants Assimilate Into or Out of Welfare?," Journal of Human Resources, 38(1).

Kaushal, N. (2005): "New Immigrants' Location Choices: Magnets without Welfare," Journal of Labor Economics, 23(1), 59-80.

NAnnestad, P. (2007): "Immigration and Welfare States: a Survey of 15 Years of Research," European Journal of Political Economy, 23, 512-532.

NoIRIEL, G. (2002): Atlas de l'immigration. Éditions Autrement, Paris.

PinçOn, M. (1981): Les immigrés et les HLM: le rôle du secteur HLM dans le logement de la population immigrée en Île-de-France. Les Presses de Copédith, Paris. 
Zavodny, M. (2005): "Determinants of Recent Immigrants' Location Choices," International Migration Review, 33, 1014-1030. 
Figure 1: Local proportions of individuals living in a social housing dwelling, in 1982 (left panel) and 1999 (right panel)
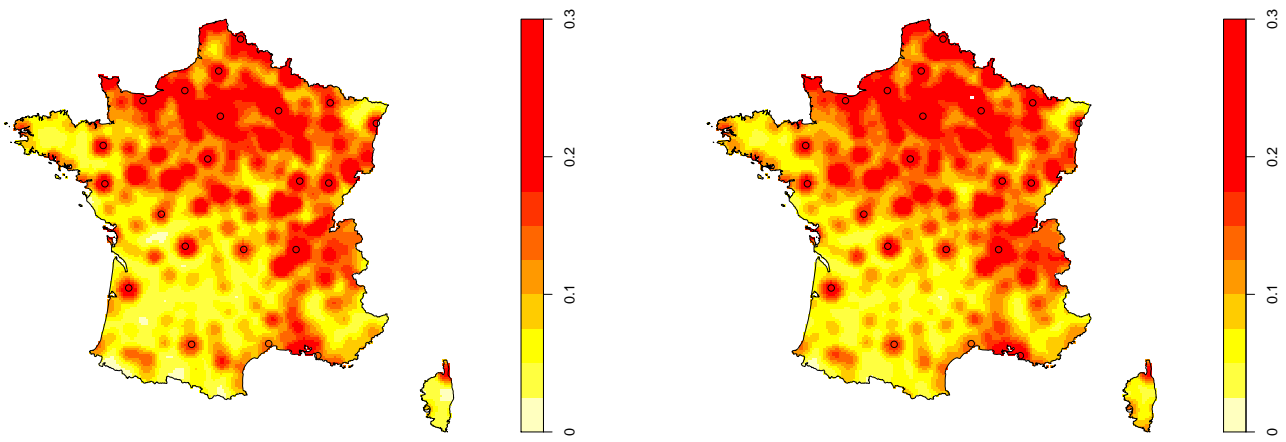

Figure 2: Local proportions of individuals living in a social housing dwelling, in 1982 (left panel) and 1999 (right panel), sample restricted to Île-de-France
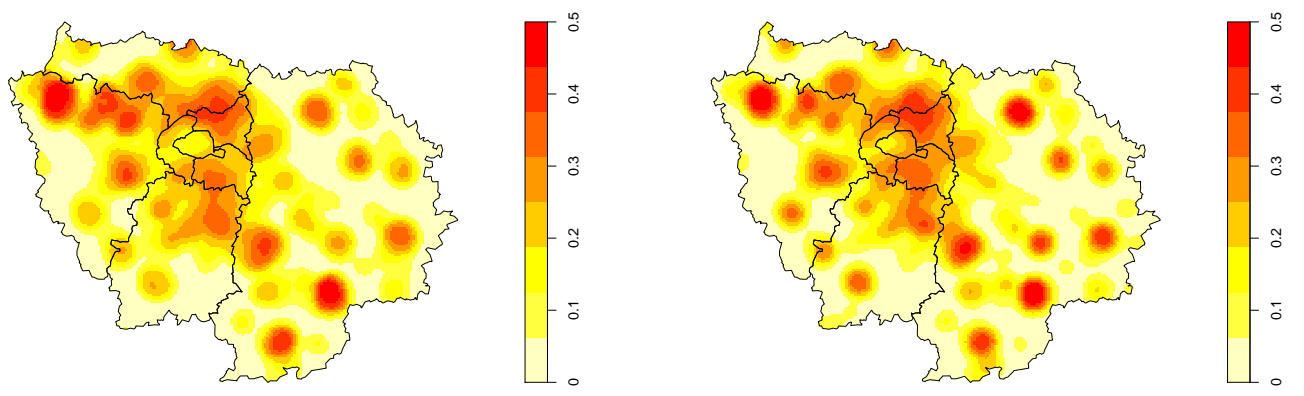
Figure 3: Local proportions of immigrants, immigrants from North-Africa, and immigrants from Southern Europe, in 1982 (left column) and 1999 (right column)

\author{
Immigrants
}
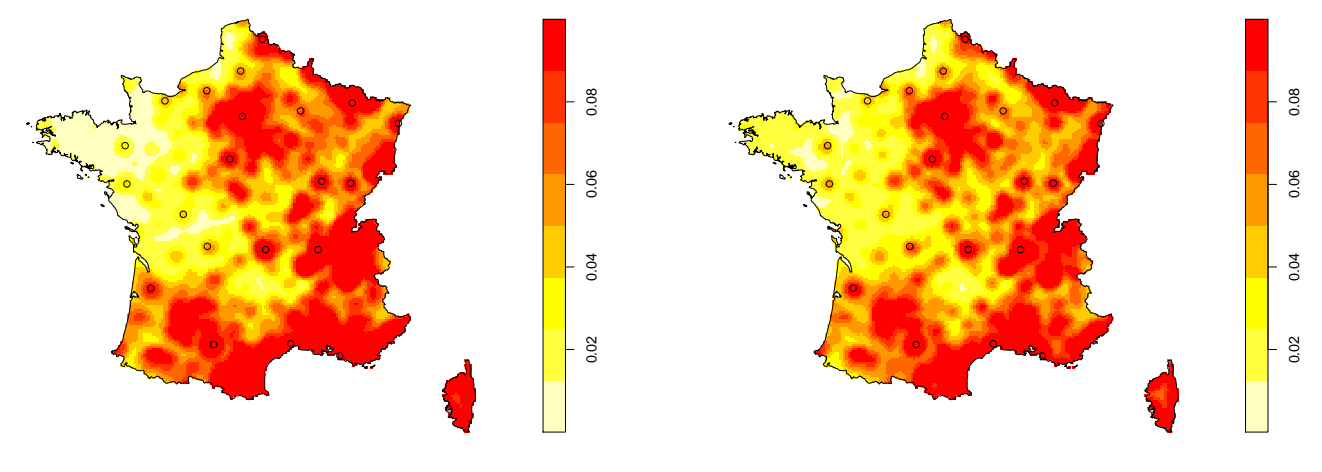

North Africans
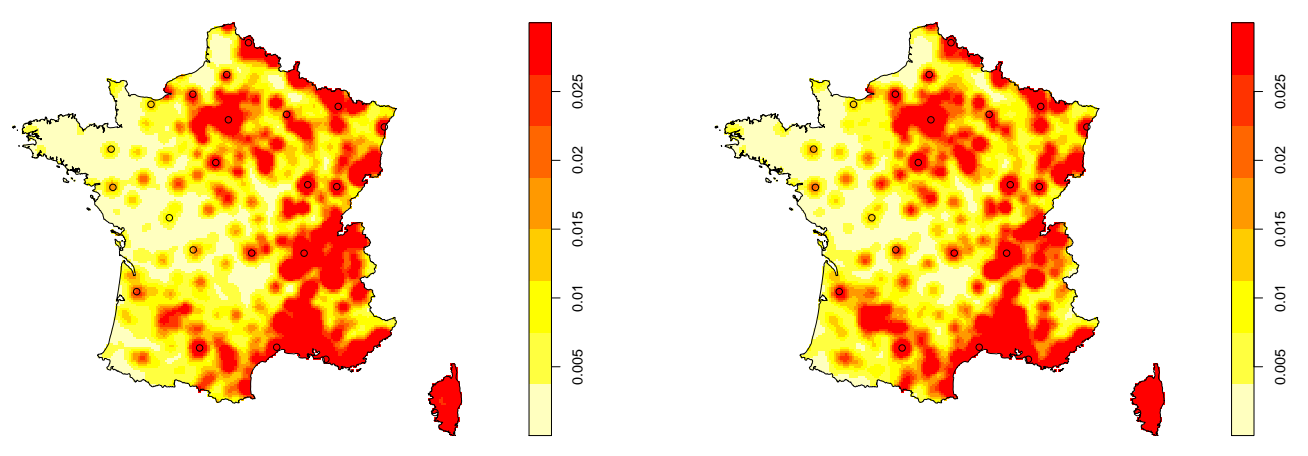

Italians, Spanish and Portuguese
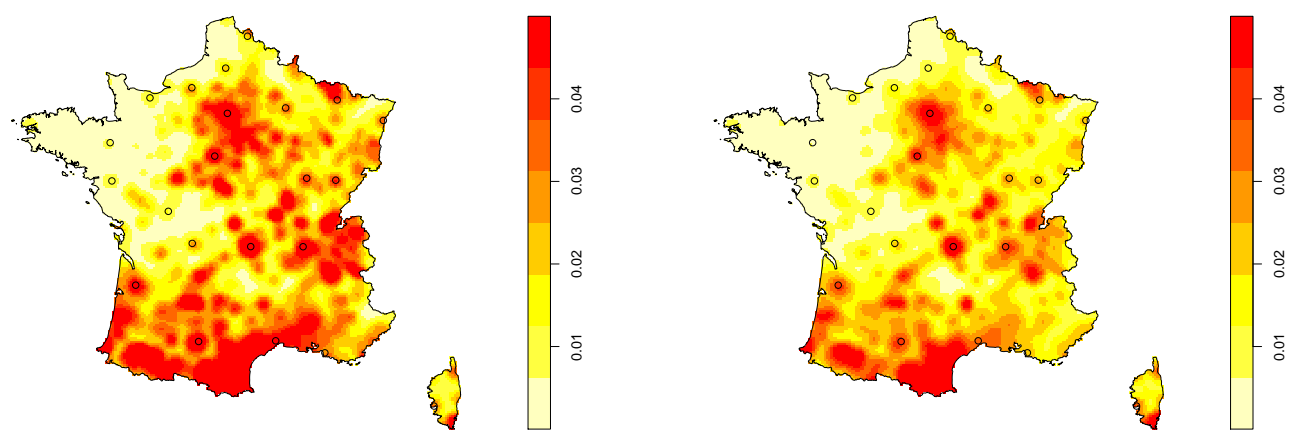
Figure 4: Local proportions of immigrants from Sub-saharan Africa, immigrants from NorthAfrica, and immigrants from Southern Europe, in 1982 (left column) and 1999 (right column), sample restricted to Île-de-France

\author{
Sub-saharan Africans
}
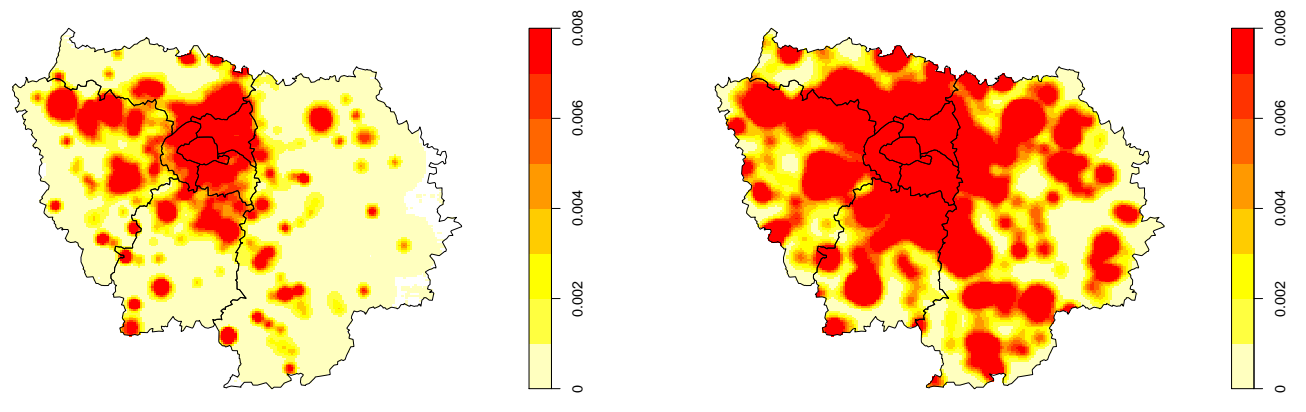

North Africans
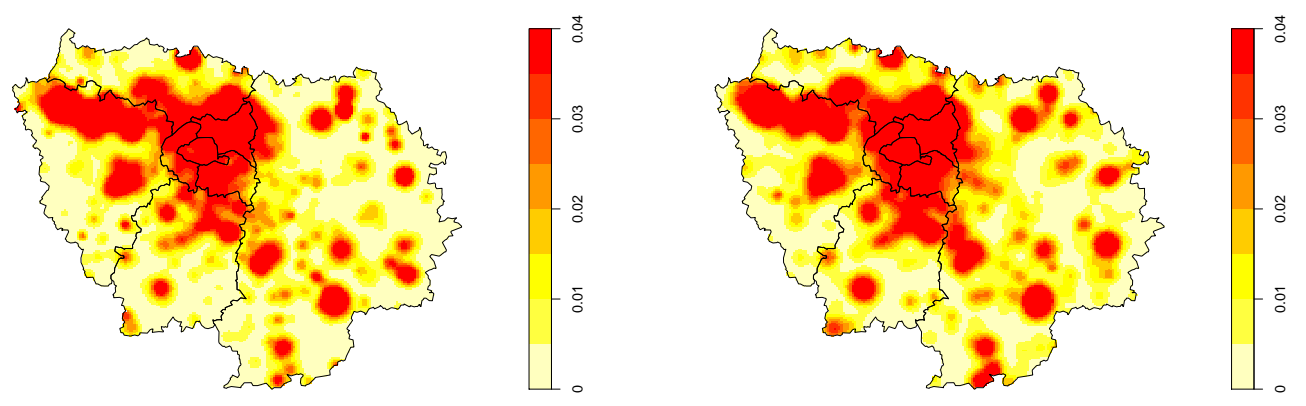

Italians, Spanish and Portuguese
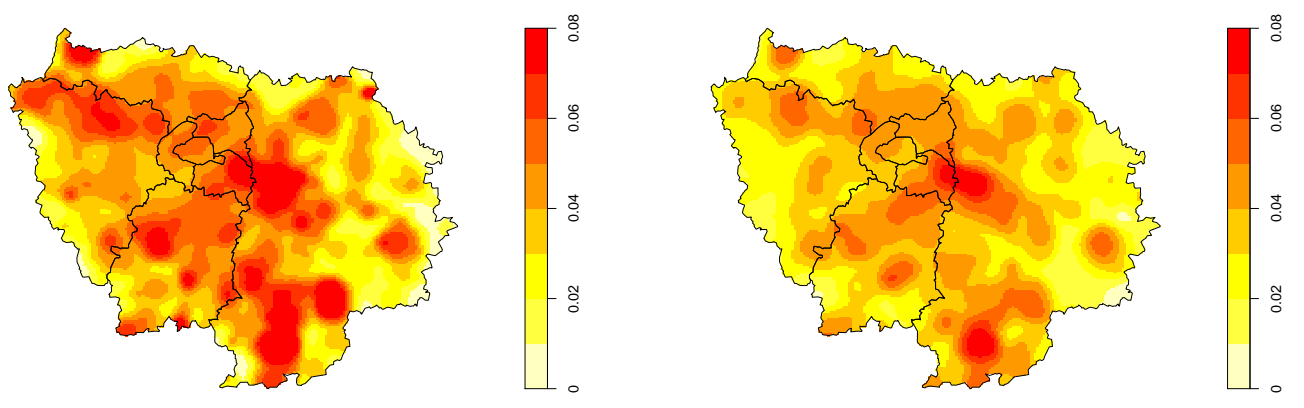
Figure 5: Odds-ratios for the probability to live in a social housing dwelling, conditional on being an immigrant, an immigrant from North-Africa, or an immigrant from Southern Europe, in 1982 (left column) and 1999 (right column)

Immigrants

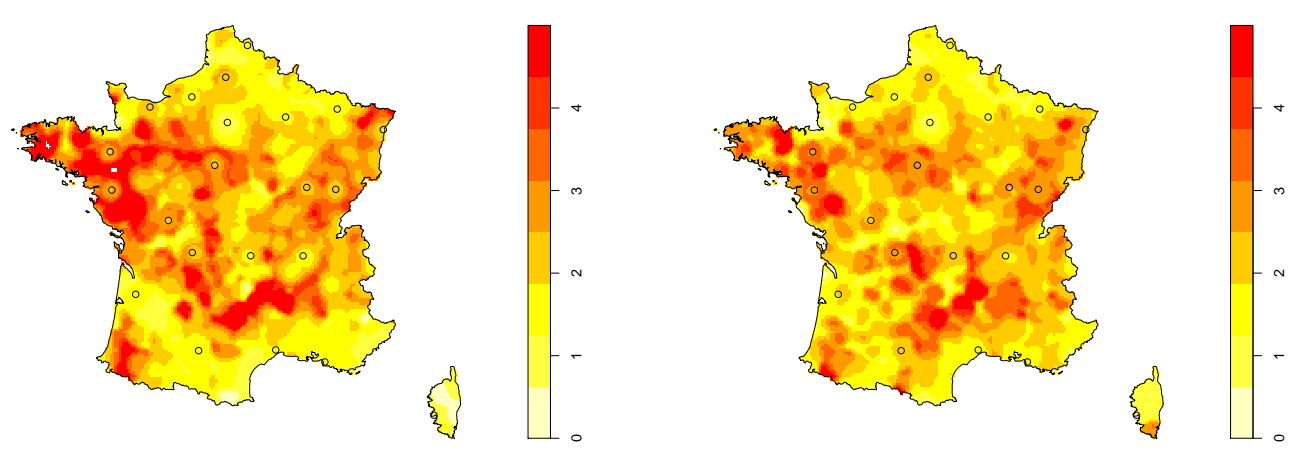

North Africans
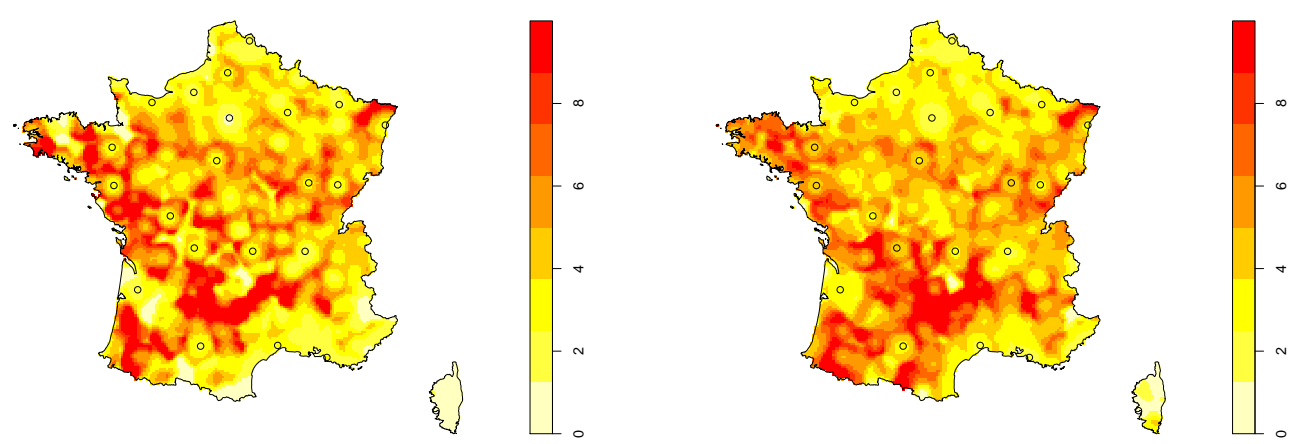

Italians, Spanish and Portuguese
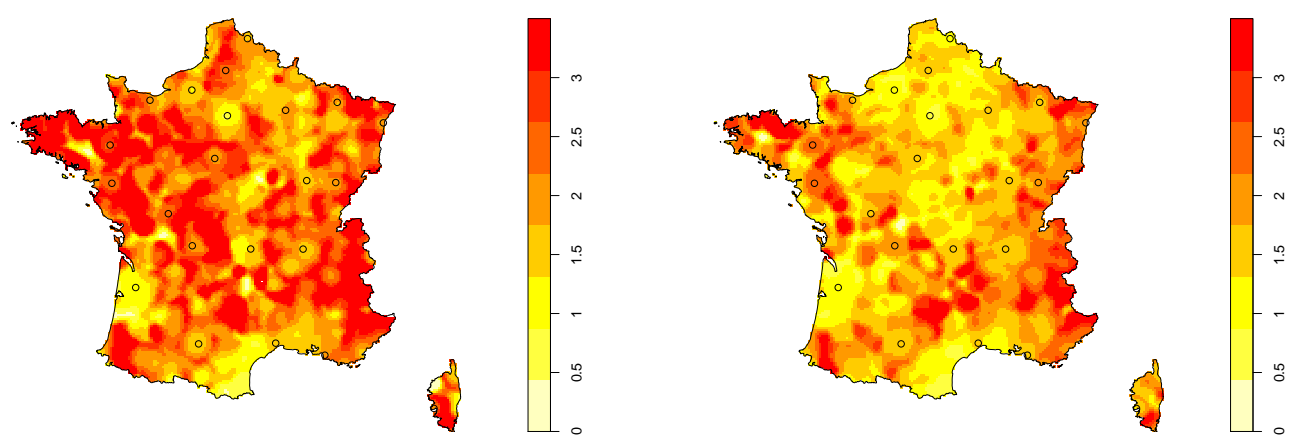
Figure 6: Odds-ratios for the probability to live in a social housing dwelling, conditional on being an immigrant from Sub-saharan Africa, an immigrant from North-Africa, or an immigrant from Southern Europe, in 1982 (left column) and 1999 (right column), sample restricted to Île-de-France

\author{
Sub-saharan Africans
}
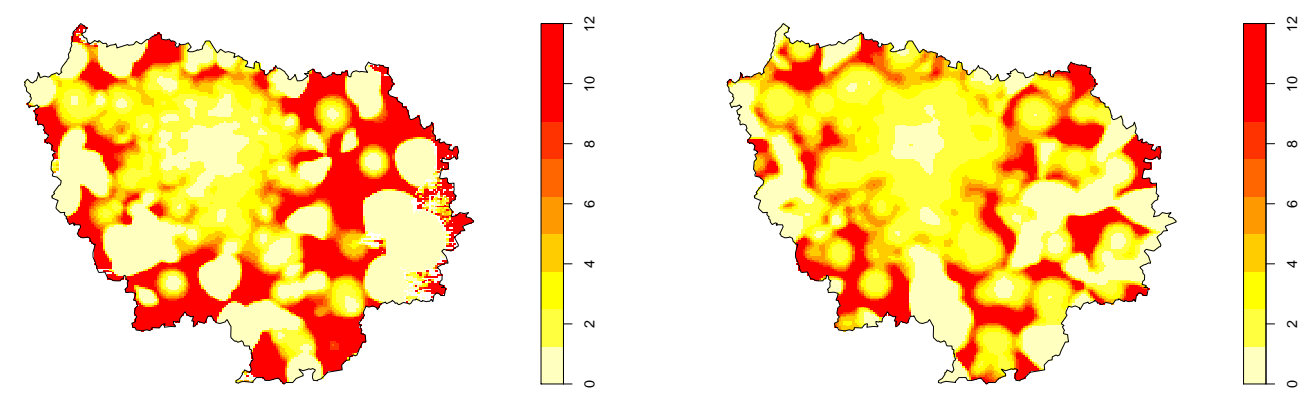

North Africans
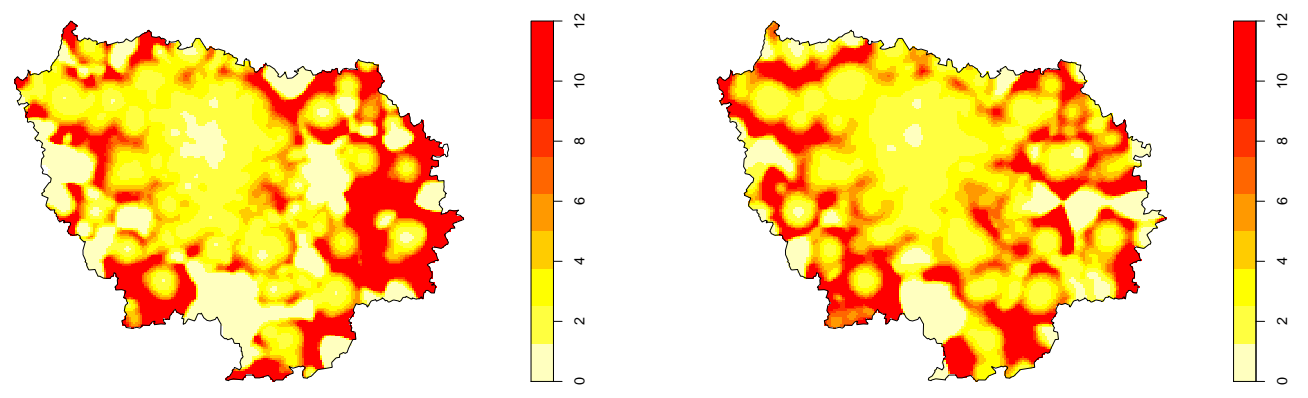

Italians, Spanish and Portuguese
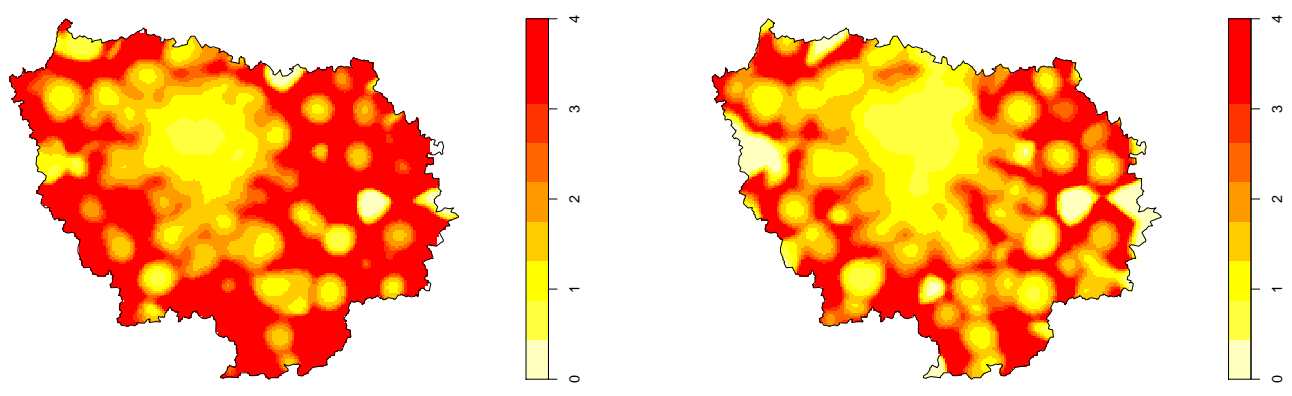
Figure 7: Simulated proportion of North-African migrants living in HLM as a function of the proportion of people living in HLM in the municipality, according to the proportions of migrants from North Africa and Southern Europe

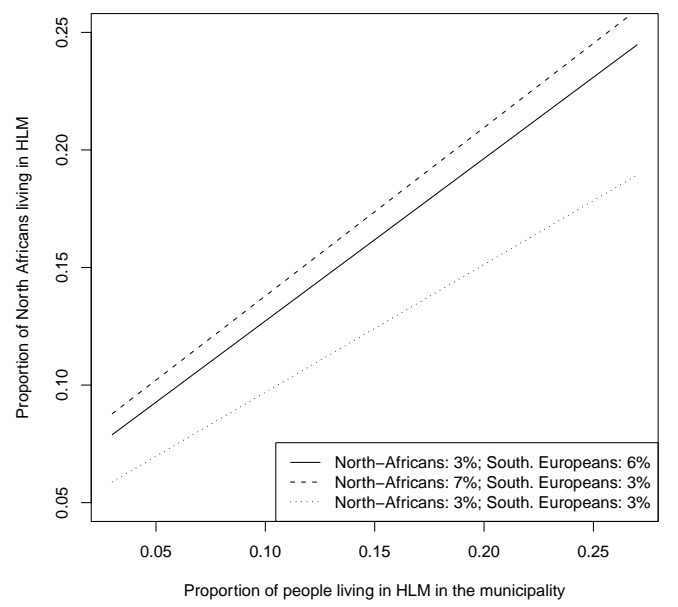

Note: Simulations based on the estimates of the model parameters reported in Table 6

Figure 8: Simulated proportion of Southern-European migrants living in HLM as a function of the proportion of people living in HLM in the municipality, according to the proportions of migrants from North Africa and Southern Europe

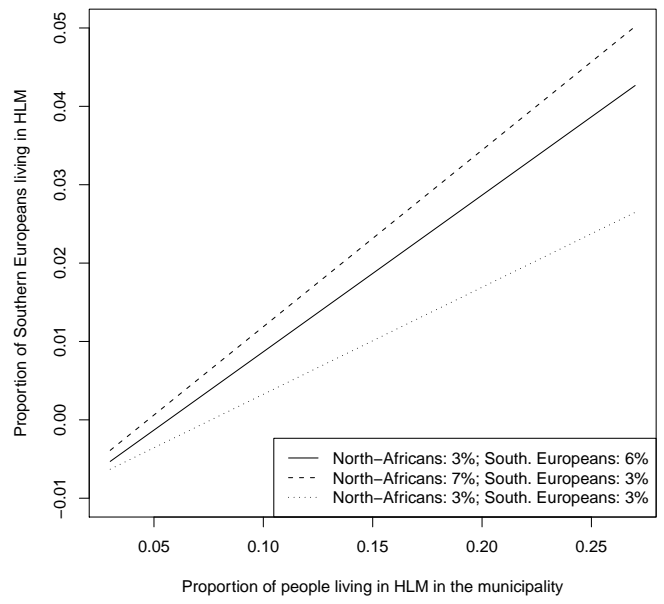

Note: Simulations based on the estimates of the model parameters reported in Table 6 
Table 1. Proportions of immigrants in France, by country of origin and census year

\begin{tabular}{|c|c|c|c|}
\hline & 1982 & 1990 & 1999 \\
\hline French natives & 0.9027 & 0.9001 & 0.8947 \\
\hline Immigrants & 0.0894 & 0.0881 & 0.0884 \\
\hline Migrants having gained French nationality & 0.0284 & 0.0292 & 0.0324 \\
\hline Immigrant from Spain & 0.0127 & 0.0111 & 0.0090 \\
\hline Migrant from Spain having gained French nationality & 0.0064 & 0.0068 & 0.0059 \\
\hline Immigrant from Portugal & 0.0137 & 0.0144 & 0.0144 \\
\hline Migrant from Portugal having gained French nationality & 0.0015 & 0.0032 & 0.0047 \\
\hline Immigrant from Italy & 0.0167 & 0.0147 & 0.0119 \\
\hline Migrant from Italy having gained French nationality & 0.0099 & 0.0097 & 0.0080 \\
\hline Immigrant from Algeria & 0.0127 & 0.0120 & 0.0126 \\
\hline Migrant from Algeria having gained French nationality & 0.0016 & 0.0022 & 0.0040 \\
\hline Immigrant from Morocco & 0.0071 & 0.0088 & 0.0117 \\
\hline Migrant from Morocco having gained French nationality & 0.0007 & 0.0013 & 0.0039 \\
\hline Immigrant from Tunisia & 0.0040 & 0.0040 & 0.0043 \\
\hline Migrant from Tunisia having gained French nationality & 0.0011 & 0.0012 & 0.0019 \\
\hline Immigrant from Turkey & 0.0018 & 0.0028 & 0.0037 \\
\hline Migrant from Turkey having gained French nationality & 0.0003 & 0.0003 & 0.0008 \\
\hline Immigrant from Western Europe & 0.0081 & 0.0083 & 0.0093 \\
\hline Migrant from Western Europe having gained French nationality & 0.0042 & 0.0038 & 0.0036 \\
\hline Immigrant from Eastern Europe & 0.0089 & 0.0078 & 0.0075 \\
\hline Migrant from Eastern Europe having gained French nationality & 0.0057 & 0.0055 & 0.0052 \\
\hline Immigrant from Sub-saharan Africa & 0.0034 & 0.0052 & 0.0076 \\
\hline Migrant from Sub-saharan Africa having gained French nationality & 0.0006 & 0.0012 & 0.0029 \\
\hline Immigrant from south-Eastern Asia & 0.0023 & 0.0031 & 0.0035 \\
\hline Migrant from south-Eastern Asia having gained French nationality & 0.0007 & 0.0014 & 0.0025 \\
\hline Immigrant from Northern America & 0.0006 & 0.0007 & 0.0008 \\
\hline Migrant from Northern America having gained French nationality & 0.0001 & 0.0001 & 0.0002 \\
\hline Immigrant from Southern America & 0.0007 & 0.0010 & 0.0014 \\
\hline Migrant from Southern America having gained French nationality & 0.0002 & 0.0003 & 0.0007 \\
\hline Immigrant from other countries & 0.0039 & 0.0061 & 0.0080 \\
\hline Migrant from other countries having gained French nationality & 0.0010 & 0.0014 & 0.0026 \\
\hline
\end{tabular}

Source: French Population Censuses, Insee, Paris, 1982, 1990 and 1999

Note: Individuals aged 18 or more 
Table 1bis. Proportions of immigrants in France, by country of origin and census year - Sample restricted to île de France

\begin{tabular}{|c|c|c|c|}
\hline & 1982 & 1990 & 1999 \\
\hline French natives & 0.8328 & 0.8171 & 0.7953 \\
\hline Immigrants & 0.1569 & 0.1669 & 0.1790 \\
\hline Migrants having gained French nationality & 0.0366 & 0.0431 & 0.0572 \\
\hline Immigrant from Spain & 0.0134 & 0.0115 & 0.0091 \\
\hline Migrant from Spain having gained French nationality & 0.0047 & 0.0053 & 0.0045 \\
\hline Immigrant from Portugal & 0.0317 & 0.0334 & 0.0344 \\
\hline Migrant from Portugal having gained French nationality & 0.0020 & 0.0054 & 0.0087 \\
\hline Immigrant from Italy & 0.0146 & 0.0126 & 0.0102 \\
\hline Migrant from Italy having gained French nationality & 0.0077 & 0.0071 & 0.0057 \\
\hline Immigrant from Algeria & 0.0240 & 0.0236 & 0.0257 \\
\hline Migrant from Algeria having gained French nationality & 0.0016 & 0.0029 & 0.0069 \\
\hline Immigrant from Morocco & 0.0122 & 0.0150 & 0.0203 \\
\hline Migrant from Morocco having gained French nationality & 0.0018 & 0.0031 & 0.0074 \\
\hline Immigrant from Tunisia & 0.0095 & 0.0100 & 0.0105 \\
\hline Migrant from Tunisia having gained French nationality & 0.0036 & 0.0041 & 0.0054 \\
\hline Immigrant from Turkey & 0.0023 & 0.0040 & 0.0053 \\
\hline Migrant from Turkey having gained French nationality & 0.0007 & 0.0008 & 0.0013 \\
\hline Immigrant from Western Europe & 0.0113 & 0.0114 & 0.0111 \\
\hline Migrant from Western Europe having gained French nationality & 0.0052 & 0.0047 & 0.0041 \\
\hline Immigrant from Eastern Europe & 0.0154 & 0.0140 & 0.0144 \\
\hline Migrant from Eastern Europe having gained French nationality & 0.0089 & 0.0085 & 0.0086 \\
\hline Immigrant from Sub-saharan Africa & 0.0115 & 0.0172 & 0.0257 \\
\hline Migrant from Sub-saharan Africa having gained French nationality & 0.0016 & 0.0037 & 0.0088 \\
\hline Immigrant from south-Eastern Asia & 0.0063 & 0.0090 & 0.0100 \\
\hline Migrant from south-Eastern Asia having gained French nationality & 0.0019 & 0.0043 & 0.0072 \\
\hline Immigrant from Northern America & 0.0016 & 0.0020 & 0.0022 \\
\hline Migrant from Northern America having gained French nationality & 0.0002 & 0.0003 & 0.0005 \\
\hline Immigrant from Southern America & 0.0024 & 0.0035 & 0.0048 \\
\hline Migrant from Southern America having gained French nationality & 0.0004 & 0.0010 & 0.0019 \\
\hline Immigrant from other countries & 0.0085 & 0.0149 & 0.0202 \\
\hline Migrant from other countries having gained French nationality & 0.0026 & 0.0040 & 0.0067 \\
\hline
\end{tabular}

Source: French Population Censuses, Insee, Paris, 1982, 1990 and 1999

Note: Individuals aged 18 or more, living in île-de-France 
Table 2. Summary statistics of the main control variables, by census year and immigrant status

- Farmer

Natives

1982

1990

Immigrant Natives

1999

0.039

0.0062

0.0252

0.0040

0.0151

Immigrants

- Executive

0.0464

0.0323

0.0421

0.0406

0.0358

0.0034

0.0490

0.0255

0.0639

0.0421

0.0707

0.0411

- Intermediate profession

0.1030

0.0396

0.1137

0.0548

0.1310

0.0534

- White-collar worker

0.1584

0.1625

0.1158

0.1720

- Blue-collar worke

0.3316

0.0076

0.1633

0.2855

0.1465

0.1519

- Unemployed who never worked before

0.0103

0.0053

0.0139

0.2256

- Out-of the labor force

0.4196

0.4512

0.4240

0.4434

0.4223

0.0165

- Self-employed

0.052

0.0265

0.0422

0.0299

0.0297

0.4343

- Employer

0.0210

0.0121

0.0196

0.0204

0.0048

0.0145

0.0142

0.0251

0.0255

0.2827

0.3864

0.0057

0.0048

0.0210

- Private-sector worker

0.2776

0.3478

0.0031

- Public-enterprise worker

0.0141

0.0354

0.1178

0.0348

0.0159

0.3015

0.3282

- Civil servant

0.0030

0.1217

0.0201

0.0066

- Apprentice

0.0017

0.0037

0.0407

0.1209

0.0537

- Clergy person

0.0015
0.0483

0.0017

0.0011

0.0022

0.0059

0.0026

- Unemployed worker

0.0668

0.0603

0.0985

0.0692

No diploma

0.3415

0.7038

0.2439

0.5421

0.1642

0.2189

0.0907

0.1992

0.1312

0.1650

0.3970

0.0654

0.0214

0.0748

0.0367

0.0769

- Vocational high-school (11th grade)

0.1608

0.0611

0.2041

0.0985

0.2397

0.0406

0.0587

0.1163

0.0560

- College graduate

0.0547

0.0309

0.0379

0.0255

0.0516

0.0495

Age

45.40

45.74

45.74

46.52

0.0819

0.0873

0.0540

0.0913

48.17

Source: French Population Censuses, Insee, Paris, 1982, 1990 and 1999

Note: Individuals aged 18 or more 
Table 2 bis. Summary statistics of the main control variables, by census year and immigrant status - Sample restricted to île de France

\begin{tabular}{|c|c|c|c|c|c|c|}
\hline & \multicolumn{2}{|c|}{1982} & \multicolumn{2}{|c|}{1990} & \multicolumn{2}{|c|}{1999} \\
\hline & \multirow[t]{2}{*}{ Natives } & \multirow[t]{2}{*}{ Immigrants } & \multirow[t]{2}{*}{ Natives } & \multirow[t]{2}{*}{ Immigrant } & \multirow[t]{2}{*}{ Natives } & \multirow[t]{2}{*}{ Immigrants } \\
\hline Occupation & & & & & & \\
\hline - Farmer & 0.0027 & 0.0006 & 0.0018 & 0.0004 & 0.0011 & 0.0003 \\
\hline - Craftsman, shopkeeper, corporate manager & 0.0404 & 0.0337 & 0.0366 & 0.0464 & 0.0308 & 0.0464 \\
\hline - Executive & 0.1040 & 0.0465 & 0.1356 & 0.0688 & 0.1493 & 0.0777 \\
\hline - Intermediate profession & 0.1449 & 0.0537 & 0.1589 & 0.0734 & 0.1740 & 0.0924 \\
\hline - White-collar worker & 0.2186 & 0.1595 & 0.1988 & 0.1651 & 0.1900 & 0.2044 \\
\hline - Blue-collar worker & 0.1286 & 0.3297 & 0.1133 & 0.2947 & 0.0914 & 0.2269 \\
\hline - Unemployed who never worked before & 0.0050 & 0.0114 & 0.0034 & 0.0130 & 0.0049 & 0.0147 \\
\hline $\begin{array}{l}\text { - Out-of the labor force } \\
\text { Employment status }\end{array}$ & 0.3559 & 0.3648 & 0.3517 & 0.3383 & 0.3585 & 0.3373 \\
\hline - Self-employed & 0.0298 & 0.0267 & 0.0289 & 0.0345 & 0.0229 & 0.0288 \\
\hline - Employer & 0.0196 & 0.0133 & 0.0187 & 0.0162 & 0.0225 & 0.0241 \\
\hline - Home help & 0.0061 & 0.0031 & 0.0051 & 0.0051 & 0.0016 & 0.0026 \\
\hline - Private-sector worker & 0.3456 & 0.4608 & 0.3375 & 0.4368 & 0.3504 & 0.4041 \\
\hline - Public-enterprise worker & 0.0547 & 0.0174 & 0.0593 & 0.0181 & 0.0328 & 0.0088 \\
\hline - Apprentice & 0.0021 & 0.0016 & 0.0028 & 0.0026 & 0.0058 & 0.0031 \\
\hline - Clergy person & 0.0008 & 0.0011 & 0.0008 & 0.0018 & 0.0003 & 0.0006 \\
\hline $\begin{array}{l}\text { - Unemployed worker } \\
\text { Diploma }\end{array}$ & 0.0434 & 0.0705 & 0.0487 & 0.1009 & 0.0621 & 0.1320 \\
\hline No diploma & 0.2703 & 0.6575 & 0.1738 & 0.4797 & 0.1049 & 0.3474 \\
\hline - Junior high-school drop-out (7th grade) & 0.1901 & 0.0813 & 0.1616 & 0.1297 & 0.1192 & 0.1095 \\
\hline - Junior high-school graduate (9th grade) & 0.0811 & 0.0269 & 0.0878 & 0.0451 & 0.0837 & 0.0651 \\
\hline - Vocational high-school (11th grade) & 0.1517 & 0.0538 & 0.1844 & 0.0888 & 0.2016 & 0.1308 \\
\hline - High-school graduate (12th grade) & 0.1146 & 0.0571 & 0.1293 & 0.0771 & 0.1339 & 0.1028 \\
\hline - College graduate & 0.0552 & 0.0224 & 0.0781 & 0.0426 & 0.1069 & 0.0658 \\
\hline - University graduate & 0.0778 & 0.0465 & 0.1056 & 0.0777 & 0.1646 & 0.1264 \\
\hline Age & 44.05 & 42.53 & 43.92 & 43.17 & 44.94 & 45.19 \\
\hline
\end{tabular}

Source: French Population Censuses, Insee, Paris, 1982, 1990 and 1999

Note: Individuals aged 18 or more, living in Île-de-France 
Table 3. Proportion of people living in a social housing dwelling, by country of origin and nationality

French native

Migrants having gained French nationality:

- Spain

- Portugal

- Italy

- Algeria

- Morocco

- Tunisia

- Turkey

- Western Europe

- Eastern Europe

- Sub-Saharan Africa

- Southeastern Asia

- Northern America

- Southern America

- Other countries

(b) Migrants without the French nationality:

- Spain

- Portugal

- Italy

- Algeria

- Morocco

- Tunisia

- Turkey

- Western Europe

- Eastern Europe

- Sub-Saharan Africa

- Southeastern Asia

- Northern America

- Southern America

- Other countries

$\begin{array}{rrr}1982 & 1990 & 1999 \\ 0.1371 & 0.1315 & 0.1414\end{array}$

$\begin{array}{lll}0.1801 & 0.1577 & 0.1462\end{array}$

$\begin{array}{lll}0.2080 & 0.2066 & 0.1995\end{array}$

$\begin{array}{lll}0.1224 & 0.1156 & 0.1143\end{array}$

$\begin{array}{lll}0.3753 & 0.3939 & 0.4406\end{array}$

$\begin{array}{lll}0.2553 & 0.3174 & 0.4835\end{array}$

$\begin{array}{lll}0.2745 & 0.2807 & 0.3990\end{array}$

$\begin{array}{lll}0.1209 & 0.1908 & 0.4022\end{array}$

$\begin{array}{lll}0.1205 & 0.1026 & 0.1074\end{array}$

$\begin{array}{lll}0.1340 & 0.1246 & 0.1738\end{array}$

$\begin{array}{lll}0.3025 & 0.3241 & 0.4461\end{array}$

$\begin{array}{lll}0.2857 & 0.2904 & 0.3168\end{array}$

$\begin{array}{lll}0.1030 & 0.0784 & 0.0750\end{array}$

$\begin{array}{lll}0.1392 & 0.1896 & 0.2637\end{array}$

$\begin{array}{lll}0.1764 & 0.1713 & 0.2112\end{array}$

$\begin{array}{lll}0.2031 & 0.2067 & 0.2013\end{array}$

$\begin{array}{lll}0.2496 & 0.2600 & 0.2306\end{array}$

$\begin{array}{lll}0.1502 & 0.1406 & 0.1412\end{array}$

$\begin{array}{lll}0.3337 & 0.4385 & 0.5006\end{array}$

$\begin{array}{lll}0.3601 & 0.4601 & 0.5113\end{array}$

$\begin{array}{lll}0.2794 & 0.3506 & 0.4325\end{array}$

$\begin{array}{lll}0.4129 & 0.4664 & 0.5037\end{array}$

$\begin{array}{lll}0.0737 & 0.0574 & 0.0510\end{array}$

$\begin{array}{lll}0.1576 & 0.1965 & 0.2407\end{array}$

$\begin{array}{lll}0.2369 & 0.2949 & 0.3983\end{array}$

$\begin{array}{lll}0.4120 & 0.4439 & 0.4611\end{array}$

$\begin{array}{lll}0.0470 & 0.0369 & 0.0485\end{array}$

$\begin{array}{lll}0.1919 & 0.2110 & 0.2545\end{array}$

$\begin{array}{lll}0.1375 & 0.1381 & 0.1633\end{array}$

Source: French Population Censuses, Insee, Paris, 1982, 1990 and 1999 Note: Individuals aged 18 or more 
Table 3bis. Proportion of people living in a social housing dwelling, by country of origin and nationality - Sample restricted to île de France

French native

Migrants having gained French nationality:

- Spain

- Portugal

- Italy

- Algeria

- Morocco

- Tunisia

- Turkey

- Western Europe

- Eastern Europe

- Sub-Saharan Africa

- Southeastern Asia

- Northern America

- Southern America

- Other countries

(b) Migrants without the French nationality:

- Spain

- Portugal

- Italy

- Algeria

- Morocco

- Tunisia

- Turkey

- Western Europe

- Eastern Europe

- Sub-Saharan Africa

- Southeastern Asia

- Northern America

- Southern America

- Other countries

$\begin{array}{rrr}1982 & 1990 & 1999 \\ 0.2117 & 0.2072 & 0.2230\end{array}$

$\begin{array}{lll}0.2629 & 0.2415 & 0.2279\end{array}$

$\begin{array}{lll}0.2545 & 0.2534 & 0.2363\end{array}$

$\begin{array}{lll}0.1696 & 0.1657 & 0.1632\end{array}$

$\begin{array}{lll}0.3961 & 0.4453 & 0.4848\end{array}$

$\begin{array}{lll}0.2519 & 0.2926 & 0.4695\end{array}$

$\begin{array}{lll}0.2978 & 0.2866 & 0.3734\end{array}$

$\begin{array}{lll}0.1335 & 0.1689 & 0.2767\end{array}$

$\begin{array}{lll}0.1351 & 0.1108 & 0.1258\end{array}$

$\begin{array}{lll}0.1510 & 0.1520 & 0.2010\end{array}$

$\begin{array}{lll}0.3064 & 0.3274 & 0.4833\end{array}$

$\begin{array}{lll}0.2739 & 0.2578 & 0.2715\end{array}$

$\begin{array}{lll}0.1055 & 0.0744 & 0.0858\end{array}$

$\begin{array}{lll}0.1382 & 0.2272 & 0.3338\end{array}$

$\begin{array}{lll}0.2041 & 0.1850 & 0.2357\end{array}$

$\begin{array}{lll}0.2158 & 0.2246 & 0.2230\end{array}$

$\begin{array}{lll}0.2304 & 0.2478 & 0.2280\end{array}$

$\begin{array}{lll}0.1676 & 0.1635 & 0.1530\end{array}$

$\begin{array}{lll}0.3114 & 0.4164 & 0.4987\end{array}$

$\begin{array}{lll}0.2999 & 0.3958 & 0.4936\end{array}$

$\begin{array}{lll}0.2499 & 0.3130 & 0.4182\end{array}$

$\begin{array}{lll}0.2147 & 0.2326 & 0.3574\end{array}$

$\begin{array}{lll}0.0771 & 0.0589 & 0.0711\end{array}$

$\begin{array}{lll}0.1469 & 0.1924 & 0.2205\end{array}$

$\begin{array}{lll}0.2067 & 0.2580 & 0.3841\end{array}$

$\begin{array}{lll}0.2896 & 0.3085 & 0.3271\end{array}$

$\begin{array}{lll}0.0433 & 0.0326 & 0.0494\end{array}$

$\begin{array}{lll}0.1531 & 0.1977 & 0.2866\end{array}$

$\begin{array}{lll}0.0987 & 0.0921 & 0.1429\end{array}$

Source: French Population Censuses, Insee, Paris, 1982, 1990 and 1999 Note: Individuals aged 18 or more, living in Île-de-France 
Table 4. Probability to live in a social housing dwelling

Intercept

Parameter Estimate Std. Error

Gender (ref. = female)

- male

$0.3453 \quad 0.0006$

Marital status (ref. =single)

- married

$-0.0173 \quad 0.0001$

Nationality and country of origin (ref. = French native)

$-0.0136 \quad 0.0002$

(a) Migrants having gained French nationality:

- Spain

- Portugal

- Italy

- Algeria

$0.0249 \quad 0.0012$

- Morocco

0.0007

$0.2448 \quad 0.0013$

$0.2572 \quad 0.0015$

- Turkey

$0.1963 \quad 0.0018$

$0.0803 \quad 0.0036$

- Western Europe

$0.0020 \quad 0.0011$

- Eastern Europe

$0.0295 \quad 0.0009$

- Sub-Saharan Africa

$0.2358 \quad 0.0017$

- Southeastern Asia

$0.1562 \quad 0.0017$

- Northern America

$-0.0249 \quad 0.0052$

- Southern America

$0.0921 \quad 0.0034$

- Other countries

$0.0677 \quad 0.0019$

b) Migrants without the French nationality:

- Spain

- Portugal

$0.0581 \quad 0.0010$

- Italy

- Algeria

0.0006

- Morocco

$0.0127 \quad 0.0009$

$0.2459 \quad 0.0007$

- Tunisia

$0.2624 \quad 0.0008$

- Turkey

$0.1703 \quad 0.0013$

$0.2717 \quad 0.0020$

- Western Europe

$0.0494 \quad 0.0010$

- Eastern Europe

$0.0539 \quad 0.0013$

- Sub-Saharan Africa

$0.1436 \quad 0.0011$

- Southeastern Asia

$0.2537 \quad 0.0018$

- Northern America

$0.0571 \quad 0.0028$

- Southern America

$0.0688 \quad 0.0025$

- Other countries

$0.0006 \quad 0.0015$

Occupation (ref. = blue-collar worker):

- Farmer

$-0.1374 \quad 0.0008$

- Craftsman, shopkeeper, corporate manager

$-0.0990$

0.0007

- Executive

- Intermediate profession

$-0.0875 \quad 0.0004$

$-0.0570 \quad 0.0003$

- White-collar worker

- Unemployed who never worked before

$-0.0094 \quad 0.0003$

$0.0090 \quad 0.0008$

- Out-of the labor force

$-0.0594 \quad 0.0002$

Employment status (ref. = private-sector worker):

- Self-employed

$-0.0275 \quad 0.0007$

- Employer

- Home help

$-0.0346 \quad 0.0007$

$-0.0562 \quad 0.0009$

$0.0230 \quad 0.0004$

Public-enterprise worker

$0.0274 \quad 0.0002$

$-0.0410 \quad 0.0011$

- Apprentice

- Clergy person

- Unemployed worker

$-0.0421 \quad 0.0021$

$0.0565 \quad 0.0003$

Diploma (ref. = No diploma):

- Junior high-school drop-out (7th grade)

- Junior high-school graduate (9th grade)

$-0.0150 \quad 0.0002$

$-0.0398 \quad 0.0003$

- Vocational high-school (11th grade)

$-0.0297 \quad 0.0002$

- High-school graduate (12th grade)

$-0.0675 \quad 0.0003$

- College graduate

$-0.0817 \quad 0.0003$

- University graduate

Age

Age squared

Census year (ref. = 1999):

- 1990

- 1982

$-0.0907 \quad 0.0004$

$-0.0031 \quad 0.0000$

$0.0000 \quad 0.0000$

$\begin{array}{ll}-0.0211 & 0.0002\end{array}$

$-0.0233 \quad 0.0002$

R2

0.0575

27312188

Source: French Population Censuses, Insee, Paris, 1982, 1990 and 1999

Note: Population living in France, aged 18 or more. OLS estimates (units: cells). 
Gender (ref $=$ female)

Parameter Estimate Std. Error

- male

$-0.0137$

0.0001

Marital status (ref $=$ single)

- married

$-0.0259 \quad 0.0002$

Nationality and country of origin (ref = French native)

- Southern Europe

- North Africa

$-0.0071 \quad 0.0020$

- Other countries

$\begin{array}{ll}0.2552 & 0.0029 \\ 0.0887 & 0.0020\end{array}$

Interaction terms between origin and local covariates:

- North African * log(total pop. in city)

- North African * prop. of people living in HLM in the city

$-0.0059 \quad 0.0003$

- North African* prop. of North African migrants in the city

$0.5483 \quad 0.0032$

- North African * prop. of Southern European migrants in the city

- North African * prop. of migrants from other countries in the city

$-1.6652 \quad 0.0128$

- Southern European $* \log$ (total pop. in city)

$-0.4806 \quad 0.0131$

$\begin{array}{rr}-0.8323 & 0.0114 \\ 0.0044 & 0.0002\end{array}$

- Southern European * prop. of people living in HLM in the city

$0.1334 \quad 0.0030$

- Southern European * prop. of North African migrants in the city

$\begin{array}{rr}0.1334 & 0.0030 \\ -0.6298 & 0.0141\end{array}$

- Southern European * prop. of Southern European migrants in the city

0.0141

- Southern European * prop. of migrants from other countries in the city

$-0.1017$

$-0.6319 \quad 0.0107$

- Other countries * log(total pop. in city)

- Other countries* prop. of people living in HLM in the city

$-0.0027 \quad 0.0002$

$0.2482 \quad 0.0030$

- Other countries * prop. of North African migrants in the city

$-0.6273 \quad 0.0142$

- Other countries * prop. of Southern European migrants in the city

0.0113

- Other countries * prop. of migrants from other countries in the city

- Farmer

$-0.0535 \quad 0.0008$

$\begin{array}{lr}\text { Craftsman, shopkeeper, corporate manager } & -0.1003\end{array}$

0.0007

- Executive

- Intermediate profession

$-0.1067 \quad 0.0004$

- White-collar worker

$\begin{array}{rr}-0.0710 & 0.0003 \\ -0.0255 & 0.0002\end{array}$

$\begin{array}{rr}0.0037 & 0.0008 \\ -0.0615 & 0.0002\end{array}$

- Out-of the labor force

Employment status (ref. = private-sector worker):

$-0.0126 \quad 0.0006$

- Self-employed

0.0007

- Employer

- Home help

$-0.0382$

0.00008

- Public-enterprise worker

0.0017

0.0004

- Civil servant

$0.0216 \quad 0.0002$

- Apprentice

$-0.0213$

0.0010

- Clergy person

$-0.0214 \quad 0.0020$

Unemployed worker

$0.0478 \quad 0.0003$

Diploma (ref. $=$ No diploma):

- Junior high-school drop-out (7th grade)

- Junior high-school graduate (9th grade)

$-0.0156 \quad 0.0002$

$-0.0456 \quad 0.0003$

$\begin{array}{ll}-0.0291 & 0.0002\end{array}$

Vocational high-school (11th grade)

\begin{tabular}{lr} 
- High-school graduate (12th grade) & -0.0675 \\
\hline
\end{tabular}

- College graduate

$-0.0823 \quad 0.0003$

- University graduate

$-0.1016$

$-0.0024 \quad 0.004$

Age

0.0000

0.0000

Age squared

0.1787

Number of cells

27312188

Source: French Population Censuses, Insee, Paris, 1982, 1990 and 1999

Note: Population living in France, aged 18 or more. Within OLS estimation with fixed effects for municipalities and census years (units: cells). Adequate corrections on the standard errors have been made to enable inference. 
Gender (ref. $=$ female)

- male

Marital status (ref. $=$ single)

- married

$-0.0137 \quad 0.0001$

Nationality and country of origin (ref = French native)

- Southern Europe

- North Africa

- Other countries

Interaction terms between origin and local covariates:

- North African * log(total pop. in city)

- North African * prop. of people living in HLM in the city

- North African * prop. of North African migrants in the city

$\begin{array}{ll}-0.0089 & 0.0003\end{array}$

- North African * prop. of Southern European migrants in the city

$\begin{array}{rr}0.8540 & 0.0076 \\ -0.5941 & 0.0195\end{array}$

- North African * prop. of migrants from other countries in the city

$\begin{array}{ll}-0.5941 & 0.0195 \\ -0.2715 & 0.0228 \\ -0.9380 & 0.0204\end{array}$

- North African * prop. of people living in $\mathrm{HLM} *$ prop. of North African migrants in the city

$-0.9380 \quad 0.0204$

$-4.3113 \quad 0.0638$

- North African * prop. of people living in HLM * prop. of migrants from other countries in the city

$\begin{array}{ll}-4.3113 & 0.0638 \\ -0.8376 & 0.0917\end{array}$

- Southern European * log(total pop. in city)

- Southern European * prop. of people living in HLM in the city

- Southern European * prop. of North African migrants in the city

$\begin{array}{rr}0.8305 & 0.0709 \\ -0.0003 & 0.0002\end{array}$

$0.3315 \quad 0.0062$

Southern European * prop. of Southern European migrants in the city

- Southern European * prop. of migrants from other countries in the city

- Southern European * prop. of people living in $\mathrm{HLM} *$ prop. of North African migrants in the city

$0.0064 \quad 0.0219$

$\begin{array}{rr}-0.0217 & 0.0117 \\ -0.4668 & 0.0164\end{array}$

$-0.4668 \quad 0.0164$

$-2.2196 \quad 0.0747$

- Southern European * prop. of people living in HLM * prop. of Southern European migrants in the city

$\begin{array}{ll}-0.8493 & 0.0648 \\ -0.7056 & 0.0718\end{array}$

Southern European * prop. of people living in $\mathrm{HLM} *$ prop. of migrants from other countries in the city

0.705690 .00718

Other countries * log(total pop. in city)

- Other countries * prop. of people living in HLM in the city

- Other countries * prop. of North African migrants in the city

- Other countries * prop. of Southern European migrants in the city

- Other countries * prop. of migrants from other countries in the city

- Other countries * prop. of people living in HLM * prop. of North African migrants in the city

$0.5113-0.0061$

$\begin{array}{ll}-0.3375 & 0.0235 \\ 0.0779 & 0.0172\end{array}$

0.07790 .0172

$-0.2758 \quad 0.0127$

- Other countries * prop. of people living in HLM * prop. of Southern European migrants in the city

$\begin{array}{ll}-0.1655 & 0.0685 \\ -1.1592 & 0.0819\end{array}$

Occupation (ref. = blue-collar worker):

- Farmer

- Craftsman, shopkeeper, corporate manager

- Executive

- Intermediate profession

- White-collar worker

- Unemployed who never worked before

- Out-of the labor force

Employment status (ref. = private-sector worker):

- Self-employed

- Employer

- Home help

- Public-enterprise worker

- Civil servant

- Apprentice

- Clergy person

- Unemployed worker

$\begin{array}{ll}-2.6790 & 0.0541 \\ -0.0535 & 0.0008\end{array}$

$\begin{array}{ll}-0.0535 & 0.0008 \\ -0.1002 & 0.0007\end{array}$

$-0.1066 \quad 0.0004$

$-0.0710 \quad 0.0003$

$\begin{array}{ll}-0.0255 & 0.0002 \\ 0.0035 & 0.0008\end{array}$

$0.0035 \quad 0.0008$

$-0.0615 \quad 0.0002$

$\begin{array}{rr}-0.0125 & 0.0006\end{array}$

0.0007

$-0.0382-0.0008$

$0.0017 \quad 0.0004$

$0.0215 \quad 0.0002$

$\begin{array}{ll}-0.0212 & 0.0010\end{array}$

$\begin{array}{ll}-0.0215 & 0.0020\end{array}$

$0.0479 \quad 0.0003$

Diploma (ref $=$ No diploma):

- Junior high-school drop-out (7th grade)

- Junior high-school graduate (9th grade)

- Vocational high-school (11th grade)

- High-school graduate (12th grade)

- College graduate

- University graduate

Age

Age squared

$-0.0156 \quad 0.0002$

$-0.0455 \quad 0.0003$

$-0.0290 \quad 0.0002$

$-0.0674 \quad 0.0002$

$\begin{array}{ll}-0.0822 & 0.0003\end{array}$

$-0.1015-0.0003$

$\begin{array}{ll}-0.0024 & 0.0000\end{array}$

$0.0000 \quad 0.0000$

R2

0.1790

Number of cells

Source: French Population Censuses, Insee, Paris, 1982, 1990 and 1999

Note: Population living in France, aged 18 or more. Within OLS estimation with fixed effects for municipalities and census years (unit: cells). Adequate corrections on the standard errors have been made to enable inference. 
Table 7. R2 of equations where only fixed-effects for municipalities are included

Dependent variable

Dummy living in a social housing dwelling

Dummy native

Dummy North African migrant

Dummy Southern European migrant

Dummy migrant from other countries

Dummy living in a social housing dwelling * native

Dummy living in a social housing dwelling * North African migrant

Dummy living in a social housing dwelling * Southern European migrant

0.1421

0.0643

0.0343

0.0359

0.1149

0.0178

0.0178
0.0146

0.0123

0.1425

0.0666

0.0341

0.0313

0.0340

0.1094

0.1094
0.0217

Dummy living in a social housing dwelling * migrant from other countries

8066029

Source: French Population Censuses, Insee, Paris, 1982, 1990 and 1999

Note: Population living in France, aged 18 or more. OLS estimates with fixed effects for municipalities and no other covariates (units: cells). 
Proportion of North-African migrants minus proportion of Southern-European migrants in the city

Parameter Estimate Std. Error R-square

Proportion of North-African migrants minus proportion of natives in the city

Proportion of North-African migrants living in HLM minus proportion of Southern-European migrants living in HLM in the cit

0.6717

0.9147

Proportion of North-African migrants living in HLM minus proportion of natives living in HLM in the city

0.8211

0.0076

Number of observations

36391

Source: French Population Censuses, Insee, Paris, 1982, 1990 and 1999

Note: Population living in France, aged 18 or more.

Each corresponds to an OLS regression of the proportion difference in 1999 on the proportion difference in 1982 (units: cities).

Intercepts are included but not reported here. 